\title{
Effect of Biodegradable Municipal Compost and Chemical Fertilizer on Yield, Nutrient Content and Uptake of Kharif Rice in New Alluvial Zone of West Bengal
}

\author{
Suman Samui*, Sukanta Pal and Biplab Show \\ Department of Agronomy, Bidhan Chandra Krishi Viswavidyalaya, Mohanpur, \\ Nadia, West Bengal, India \\ *Corresponding author
}

\section{A B S T R A C T}

\begin{tabular}{l} 
Ke y w o r d s \\
Municipal \\
biodegradable \\
waste, Commercial \\
compost, Chemical \\
fertilizer, Yield, \\
Nutrient content \\
and uptake, Rice \\
Article Info \\
\hline $\begin{array}{l}\text { Accepted: } \\
10 \text { October } 2020 \\
\text { Available Online: } \\
10 \text { November } 2020\end{array}$ \\
\hline
\end{tabular}

\section{Introduction}

Rice (Oryza sativa L.) is one of the most important cereal crops of India and is used as a staple food for more than $60 \%$ of the total population of the country (DAC, 2010). It accounts for about $43 \%$ of total food grain production and $55 \%$ of total cereal production in India (Singh et al., 2012). About 56\% of West Bengal's gross cropped area has been occupied by rice and ranks first in terms of cultivated area (Directorate of Agriculture,
Go W.B, 2018). The average yield of rice in West Bengal $\left(2.88 \mathrm{t} \mathrm{ha}^{-1}\right)$ has augmented as a result of several research activities, but it is still much less than other leading rice growing states in the country. In India, during the past three decades intensive agriculture involving high yielding varieties of rice has led to heaving withdraw of nutrients from the soil. Furthermore, imbalance use of only chemical fertilizers by farmers has deteriorated soil health and declines soil organic carbon content, which is the threat to sustainability. 
Application of chemical fertilizer without conservation of soil fertility not only results in depletion of soil nutrient reserve but disrupts the biological balance of soil-plant system also. Therefore, it is time to look for measures to stimulate sustainability in production of rice on long term basis (Mandal and Adhikary, 2005). On the other hand switching on food production to organic would lower crop yields, we can use all the organics that are available but we are not going to feed six billion people with organic fertilizer or materials. Therefore, pure organic agriculture will not be the substitute to combat against the harmful effect of pure chemical agriculture. At this juncture, it is essential for us to evolve and adopt a strategy of integrated nutrient supply by using a judicious combination of chemical fertilizers, organic manures and biofertilizers (Swaminathan, 1981).

Traditional composting of organic matter wastes has been known for many years but new methods of thermophilic composting have become much more popular in organic waste treatment recently since they eliminate some of the detrimental effects of organic wastes in the soil. Composting has been recognized as a low cost and environmentally sound process for treatment of many organic wastes (Hoitink, 1993). Municipal waste composting not only a viable option for municipal solid waste management (MSWM) but also desirable - socially, economically and environmentally. Organic waste composting techniques have been extensively developed in recent decades in response to the increasing concern regarding management of waste. On an average, an individual produces about 250-400g of wet wastes per day. In Bangalore city alone, about 6000 tonnes of garbage is being produced each day and the solid waste is not utilized scientifically. The wet waste contains enormous quantity of major and micro nutrients that are useful in agriculture as organic resources. Recycling of waste is possible for better utilization in agriculture, and if it is properly managed, it could be a valuable and alternative resource of plant nutrient for the imported and expensive inorganic fertilizers. Composting municipal solid waste is a method of diverting organic waste materials from landfills while creating a product, at relatively low-cost, that is suitable for agricultural purposes. This trend may be attributed to economic and environmental factors, such as municipal landfill capacity, costs associated with land filling and transportation of materials, decreasing the use of commercial fertilizers, increasing the capacity for household waste recycling and improved quality of compost products. Keeping these in view, a field study was carried out to find out the use of municipal compost along with chemical fertilizers as a source of nutrients for rice crop.

\section{Materials and Methods}

Field trial was conducted in the sub Regional Research Sub-Station (RRSS), Chakdaha, Nadia under Bidhan Chandra Krishi Viswavidyalaya, Mohanpur, West Bengal (located at $2305.3^{\prime} \mathrm{N}$ latitude and $8305.3^{\prime} \mathrm{E}$ longitude and at an elevation of 9.75 meters above the mean sea level), during kharif season of 2018 and 2019 on rice (cv. IET 4786). The climate of the experimental site is humid subtropical with mild short winter and hot humid long summer. The experiment was conducted under irrigated shallow low land situation, having medium fertility status with good drainage facility. The experimental soil was sandy loam in texture (order Inceptisol), neutral in reaction $(\mathrm{pH} 7.5)$ and medium in total nitrogen $\left(187.5 \mathrm{~kg} \mathrm{ha}^{-1}\right)$, available phosphorus $\left(16 \mathrm{~kg} \mathrm{ha}^{-1}\right)$ and available potassium $\left(129 \mathrm{~kg} \mathrm{ha}^{-}\right.$ $\left.{ }^{1}\right)$. The experimental site has average rainfall of $1450 \mathrm{~mm}, 75 \%$ of which is received during June to September. 
Field trial was designed in a simple randomized complete block design (RCBD) with three (3) replications and seven treatments [ $\mathrm{T}_{1}$ : Absolute control (No inorganic \& No compost); $\mathrm{T}_{2}$ :Recommended Dose of Fertilizer (RDF); $\mathrm{T}_{3}: \mathrm{RDF}+$ KrishiRasayan (KR) Compost (Commercial compost) @ 3.75 $\mathrm{t}$ ha $^{-1} ; \mathrm{T}_{4}$ : RDF + Ecovio (E.V.) Compost (source separated organic waste material) @ $3.75 \mathrm{t} \mathrm{ha}^{-1} ; \mathrm{T}_{5}: 50 \% \mathrm{RDF}+\mathrm{KR}$ Compost @ $3.75 \mathrm{t} \mathrm{ha}^{-1 ;} \mathrm{T}_{6}: \mathrm{RDF}+$ KrishiRasayan Compost @ $3.75 \mathrm{t} \mathrm{ha}^{-1}+$ Mulch (Decomposible polythene Mulch); $\mathrm{T}_{7}: \mathrm{RDF}+$ Ecovio Compost @ $3.75 \mathrm{t} \mathrm{ha}^{-1}+$ Mulch (Decomposible polythene Mulch)]. Nitrogen, phosphorus and potassium at the rate of 60 , 30 and $30 \mathrm{kgha}^{-1}$ in the form of urea, SSP and MOP across all treatment was considered RDF. One-fourth $\left(14^{\text {th }}\right) \mathrm{N}$ along with full $\mathrm{P}_{2} \mathrm{O}_{5}$ and $3 / 4^{\text {th }} \mathrm{K}_{2} \mathrm{O}$ of $\mathrm{RDF}$ were applied as basal (during final land preparation). Remaining $1 / 2$ $\mathrm{N}$ was top-dressed at tillering stage, while $1 / 4^{\text {th }}$ each of $\mathrm{N}$ and $\mathrm{K}_{2} \mathrm{O}$ was given at panicle initiation stage. Municipal composts were applied to the individual plots one week before transplanting. Well germinated seeds of Satabdi (IET-4786) were sown on $26^{\text {th }}$ June and $28^{\text {th }}$ June of 2018 and2019 respectively 25 days old seedlings were transplanted @ 3 seedlings per hill with a spacing of $20 \mathrm{~cm} x$ $15 \mathrm{~cm}$ in both the years. All the plots were separated by about $20 \mathrm{~cm}$ ridges to stop water/nutrients movement among the treatments. Water to each treatment was distinctly applied from irrigation channel. All other agronomic practices were done uniformly for all the trail units during rice growing season. The individual plot size was $14 \mathrm{~m} \times 7 \mathrm{~m}$. The crop was harvested when the plant become yellowish to brown and had around $14 \%$ grain moisture during $3^{\text {rd }}$ week of October. Harvested crops were kept in the field for 2-3 days for sun-drying and then threshing was done. Grain and straw were then properly sun-dried, weighed and finally converted into $\mathrm{t} / \mathrm{ha}$. Plant samples from each treatment were collected, oven-dried, and ground for analyzing total recoveries of $\mathrm{N}, \mathrm{P}$ and $\mathrm{K}$ at harvesting following standard procedures.

Data on all measured attributes of rice was subjected to analysis of variance (ANOVA) according to the techniques define for simple randomized complete block design (RCBD) as described by Gomez and Gomez (1984). Means between treatments were compared via CD (Critical difference) test $(p \leq 0.05)$. Pearson's correlation co-efficient was calculated to describe the degree and pattern of associations between observed traits of tested rice cultivar.

\section{Results and Discussion}

\section{Yield and harvest index}

Grain yield, straw yield and harvest index were significantly varied among the different combinations of nutrient management (Table 1). Grain yield ranges from $2.98 \mathrm{t} \mathrm{ha}^{-1}$ in control treatment to $4.98 \mathrm{t} \mathrm{ha}^{-1}$ in plots treated with chemical fertilizer integration with Ecovio compost and biodegradable mulch $\left(\mathrm{T}_{7}\right)$. The percentage increase in the grain yield of rice was the lowest $(37.6 \%)$ in $\mathrm{T}_{5}$ (50\% RDF + KrishiRashayan Compost) while the highest percent increase in rice grain yield $(67.1 \%)$ was observed in $\mathrm{T}_{7}$ treatment. With respect to the control plot, application of biodegradable mulch in the plots receiving integrated use of organic manures and chemical fertilizers resulted in higher percent of grain yield $(64.93 \%)$ compared to the no mulch treated plots $(52.46 \%)$. All the treatment combinations are statistically at par with $\mathrm{T}_{7}$ except $\mathrm{T}_{1}$ and $\mathrm{T}_{5}$ treatments. Kavitha et al., (2007) also found that the enriched waste compost treatment in conjunction with inorganic fertilizer has produced higher grain yield than the application of inorganic fertilizer alone. 
Table.1 Effect of municipal compost and chemical fertilizer on yield and harvest index of kharif rice (mean data of 2 years)

\begin{tabular}{|c|c|c|c|}
\hline Treatment & Grain Yield ( $\left.\mathrm{t} \mathrm{ha} \mathbf{a}^{-1}\right)$ & Straw Yield $\left(\mathrm{t} \mathrm{ha}^{-1}\right)$ & Harvest Index (\%) \\
\hline $\mathbf{T}_{1:}$ Absolute control & 2.98 & 4.78 & 38.40 \\
\hline$T_{2}:$ Recommended Dose of Fertilizer (RDF) & 4.96 & 5.10 & 49.31 \\
\hline $\mathrm{T}_{3}: \mathrm{RDF}+\mathrm{KR}$ Compost @ $3.75 \mathrm{t} \mathrm{ha}^{-1}$ & 4.73 & 4.80 & 47.36 \\
\hline $\mathrm{T}_{4}: \mathrm{RDF}+$ Ecovio Compost @ $3.75 \mathrm{t} \mathrm{ha}^{-1}$ & 4.80 & 5.15 & 48.70 \\
\hline $\mathrm{T}_{5}: 50 \% \mathrm{RDF}+\mathrm{KR}$ Compost @ $3.75 \mathrm{t} \mathrm{ha}^{-1}$ & 4.10 & 5.26 & 43.82 \\
\hline $\mathrm{T}_{6}:$ RDF + KR Compost @ $3.75 \mathrm{t} \mathrm{ha}^{-1}+$ Mulch & 4.85 & 5.30 & 47.76 \\
\hline $\mathbf{T}_{7:}$ RDF + Ecovio Compost @ $3.75 \mathrm{t} \mathrm{ha}^{-1}+$ Mulch & 4.98 & 5.16 & 49.11 \\
\hline $\operatorname{S.Em}( \pm)$ & 0.16 & 0.07 & 0.85 \\
\hline $\mathrm{CD}(\mathrm{P}=\mathbf{0 . 0 5})$ & 0.493 & 0.216 & 2.619 \\
\hline
\end{tabular}

Table.2 Effect of municipal compost and chemical fertilizer on nutrient content and uptake by straw (mean data of 2 years)

\begin{tabular}{|c|c|c|c|c|c|c|}
\hline \multirow[t]{2}{*}{ Treatment } & \multicolumn{2}{|c|}{$\mathbf{N}$} & \multicolumn{2}{|c|}{$\mathbf{P}$} & \multicolumn{2}{|c|}{$\mathbf{K}$} \\
\hline & $\begin{array}{c}\text { Content } \\
(\%)\end{array}$ & $\begin{array}{c}\text { Uptake } \\
\left(\mathrm{kg} \mathrm{ha}^{-1}\right)\end{array}$ & $\begin{array}{c}\text { Content } \\
(\%)\end{array}$ & $\begin{array}{c}\text { Uptake } \\
\left(\mathrm{kg} \mathrm{ha}^{-1}\right)\end{array}$ & $\begin{array}{c}\text { Content } \\
(\%)\end{array}$ & $\begin{array}{c}\text { Uptake } \\
\left(\mathrm{kg} \mathrm{ha}^{-1}\right)\end{array}$ \\
\hline $\mathbf{T}_{1}$ : Absolute control & 0.896 & 42.83 & 0.370 & 17.69 & 2.225 & 106.36 \\
\hline$T_{2}:$ Recommended Dose of Fertilizer (RDF) & 1.138 & 58.04 & 0.393 & 20.04 & 2.236 & 114.04 \\
\hline $\mathrm{T}_{3}:$ RDF + KR Compost @ $3.75 \mathrm{t} \mathrm{ha}^{-1}$ & 1.192 & 57.22 & 0.405 & 19.44 & 2.238 & 107.42 \\
\hline $\mathrm{T}_{4}: \mathrm{RDF}+$ Ecovio Compost @ $3.75 \mathrm{t} \mathrm{ha}^{-1}$ & 1.246 & 64.17 & 0.405 & 20.86 & 2.241 & 115.41 \\
\hline $\mathrm{T}_{7:}$ RDF + Ecovio Compost @ $3.75 \mathrm{t} \mathrm{ha}^{-1}+$ Mulch & 1.408 & 72.65 & 0.417 & 21.52 & 2.333 & 120.38 \\
\hline $\operatorname{S.Em}( \pm)$ & 0.00679 & 0.365 & 0.00114 & 0.076 & 0.002 & 0.196 \\
\hline $\mathrm{CD}(\mathrm{P}=\mathbf{0 . 0 5})$ & 0.02091 & 1.138 & 0.00353 & 0.238 & 0.007 & 0.612 \\
\hline
\end{tabular}


Table.3 Effect of municipal compost and chemical fertilizer on nutrient content and uptake by grain (mean data of 2 years)

\begin{tabular}{|c|c|c|c|c|c|c|}
\hline \multirow[b]{2}{*}{ Treatment } & \multicolumn{2}{|c|}{$\mathbf{N}$} & \multicolumn{2}{|c|}{$\mathbf{P}$} & \multicolumn{2}{|c|}{$\mathbf{K}$} \\
\hline & $\begin{array}{c}\text { Content } \\
(\%)\end{array}$ & $\begin{array}{l}\text { Uptake } \\
\left(\mathrm{kg} \mathrm{ha}^{-1}\right)\end{array}$ & $\begin{array}{c}\text { Content } \\
(\%)\end{array}$ & $\begin{array}{l}\text { Uptake } \\
\left(\mathrm{kg} \mathrm{ha}^{-1}\right)\end{array}$ & $\begin{array}{c}\text { Content } \\
(\%)\end{array}$ & $\begin{array}{c}\text { Uptake } \\
\left(\mathrm{kg} \mathrm{ha}^{-1}\right)\end{array}$ \\
\hline $\mathbf{T}_{1:}$ Absolute control & 2.140 & 63.78 & 1.3103 & 39.05 & 0.314 & 9.36 \\
\hline $\mathrm{T}_{3}: \mathrm{RDF}+\mathrm{KR}$ Compost @ $3.75 \mathrm{t} \mathrm{ha}^{-1}$ & 2.395 & 113.28 & 1.3326 & 63.03 & 0.322 & 15.23 \\
\hline $\mathrm{T}_{4}: \mathbf{R D F}+$ Ecovio Compost @ $3.75 \mathrm{t} \mathrm{ha}^{-1}$ & 2.665 & 127.92 & 1.5434 & 74.08 & 0.324 & 15.55 \\
\hline $\mathrm{T}_{5}: 50 \%$ RDF + KR Compost @ $3.75 \mathrm{t} \mathrm{ha}^{-1}$ & 3.020 & 123.82 & 1.6873 & 69.18 & 0.326 & 13.37 \\
\hline $\mathbf{T}_{7:}$ RDF + Ecovio Compost @ $3.75 \mathrm{t} \mathrm{ha}^{-1}+$ Mulch & 3.147 & 156.72 & 2.2061 & 109.86 & 0.328 & 16.33 \\
\hline $\operatorname{S.Em}( \pm)$ & 0.01725 & 0.640 & 0.01307 & 0.449 & 0.00019 & 0.052 \\
\hline $\mathrm{CD}(\mathrm{P}=\mathbf{0 . 0 5})$ & 0.05316 & 1.993 & 0.04029 & 1.399 & 0.00060 & 0.163 \\
\hline
\end{tabular}


Minor variations in rice straw yield among different treatments were observed. Compared to the control treatment, chemical fertilizer integrated with organic amendments, in general, resulted in an increase in rice straw yield. The percentage increase in the straw yield of rice was the lowest $(0.42 \%)$ in $\mathrm{T}_{3}$ $(100 \%$ RDF + KrishiRashayan Compost) while the highest $\%$ increase in rice straw yield $(10.9 \%)$ was observed in plots treated with chemical fertilizer integrated with KrishiRashayan compost and biodegradable mulch $\left(\mathrm{T}_{6}\right)$. The percent increase in rice straw yield in plots treated with Ecovio Compost and Ecovio biodegradable mulch $\left(\mathrm{T}_{6}\right)$ was comparable with that in $\mathrm{T}_{7}$. Azad and Lehria, 2001 also reported that the application of FYM@ $10 \mathrm{t} \mathrm{ha}^{-1}$ in conjunction with different chemical fertilizer levels exhibited a significant increase in straw yield of rice compared to the application sole fertilizer.

The highest percentage increase in harvest index $(28.4 \%)$ was observed in plots treated with chemical fertilizer alone $\left(\mathrm{T}_{2}\right)$. Lower level of fertilizer application (50\% of RDF) in $\mathrm{T}_{5}$ effectuated lower harvest index $(43.82 \%)$ also. The percent increase in harvest index $(\%)$ in plots treated with Ecovio Compost and Ecovio biodegradable mulch $\left(\mathrm{T}_{7}\right)$ was higher than in $\mathrm{T}_{6}$ treatment. Findings of results indicated higher harvest index $(\%)$ in the treated plots in comparison to the control plot.

\section{Nutrient content and uptake of grain and straw}

Significantly highest nitrogen uptake in grain and straw was recorded in the treatment, which received inorganic fertilizer along with Ecovio municipal compost with biodegradable mulch $\left(\mathrm{T}_{7}\right)$ which is significantly higher than all the treatments for grain uptake and it is at par with the treatment T6 (RDF + KrishiRasayan Compost @ 3.75 t $\mathrm{ha}^{-1}+$ Mulch) in case of straw uptake. The favourable effect of organics on $\mathrm{N}$ uptake could be attributed to the release of $\mathrm{N}$ during decomposition of organic materials and their uptake by crop. Similar results were obtained by Balasubramanian et al., (2002). SailajaKumari and UshaKumari (2002) reported among the different treatments tried, enriched vermicompost showed significantly highest yield and uptake of major nutrients.

Higher uptake of phosphorus in straw was recorded in treatment which comprised of KrishiRashayan compost with chemical fertilizers and mulch $\left(T_{6}\right)$ which is which is significantly higher than all the treatments (Table 2). However, in grain uptake highest phosphorus uptake recorded in case of integrated use of Ecovio municipal compost and chemical fertilizers $\left(\mathrm{T}_{7}\right)$ which is also recorded significantly higher than all the treatments (Table 3). In both grain and straw uptake of phosphorus recorded significantly higher in case of treated plots than control plot. The increased uptake of $\mathrm{P}$ may be ascribed to higher rates of $\mathrm{N}$, increased root and shoot growth and also more availability of nutrients from the added fertilizers and the solubility action of organic acids produced during the decomposition of organic materials thus, resulting in more release of both of native and applied P nutrients (Bellaki et al., 1997).

Significantly highest uptake of potassium in grain and straw was recorded in treatment, received integrated management of Ecovio municipal compost and chemical fertilizers $\left(\mathrm{T}_{7}\right)$ which is at par with the treatment, received integrated use of commercial KrishiRashayan compost and chemical fertilizers with mulch $\left(\mathrm{T}_{6}\right)$ in case of straw uptake and in case of grain uptake recorded significantly varied with all the treatments. All the treated plots recorded more $\mathrm{K}$ uptake than the control plot. The increased uptake of $\mathrm{K}$ may be ascribed to more availability to the nutrients from the added fertilizers and the solubility action of organic acids produced 
during decomposition of organic materials, thus resulting in more release of both native and applied K nutrients (Bellaki et al., 1997). Further it might be due to continuous availability of nutrients throughout crop growth period due to organic and inorganic sources were available to crop at early stages. Davari and Sharma (2010) indicated that application of FYM has significantly increased the uptake of major nutrients by rice grain over control.

From this experiment, it can be concluded that efficient use of municipal compost with chemical fertilizers not only increase yield of kharif rice but also increase the nutrient content and uptake of grain and straw as well as improves soil quality. Use of municipal compost to produce compost for agricultural use is so much vulnerable for our environment.

\section{References}

Azad, B.S. and Lehria, S.K. 2001. Yield of rice through integrated nutrient management under irrigated conditions. Annals of Agricultural Research, 22: 471-475.

Balasubramanian, A., Siddramappa, R. and Rangaswami, G. 1972. Effect of organic manuring on the activities of the enzymes hydrolyzing sucrose and urea and on soil aggregation. Plant and Soil., 37: 319-328.

Bellakki, M.A., Badanur, V.P. and Setty, R.A. 1998. Effect of long-term integrated nutrient management on some important properties of a vertisol. J. Indian Soc. Soil., 46 (2): 176-180.

Davari, M.R. and Sharma, S.N. 2010. Effect of different combinations of organic materials and bio-fertilizers on productivity, grain and economics in organic farming of basmati rice (Oryza sativa L.). Indian J. Agron., 55(4): 290-294.
Department of Agriculture \& Cooperation (2010) Ministry of Agriculture, Government of India. Guidelines for Seed Production of Hybrid Rice. Available on http://vikaspedia.in/agriculture/cropproduction/package-of-practices/hybridrice-seed-production access on 26.08.2018

Directorate of Agriculture, Go. WB. 2018. Estimates of area, yield rate and production of principal crops in West Bengal. Evaluation Wing, Directorate of Agriculture, Government of West Bengal: 23-36.

Gomez, KA. and Gomez, AA. 1984. Statistical Procedures for Agricultural Research. John Wiley and Sons, New York.

Hoitink, H.A.J. 1993. Proceedings Review: International Symposium on composting research. Compost Science and Utilization.Spring. Pp. 37.

Kavitha, R. and Subramanian, P. 2007. Effect of enriched municipal solid waste compost application on growth, plant nutrient uptake and yield of rice. J. Agron., 6(4): 586-592.

Mandal, S. and Adhikary, J. 2005.Effect of integrated nutrient management on growth and yield of rice (Oryza sativa L.).Agricultural Sciences Digest, 25(2):136138.

SailajaKumari, M.S. and UshaKumari, K. 2002. Effect of vermicompost enriched with rock phosphate on the yield and uptake of nutrients in cowpea (Vigna unguiculata L. Walp). Journal of Tropical Agriculture.40: 27-30.

Singh, C., Singh, P., Singh, R.2012.Modern Techniques of Raising Field crops. Oxford \& IBH publishing Company Pvt. Ltd. New Delhi. (Second edition).

Swaminathon, MS. 1981. In - Biofertilizer in Agriculture. Edited by N.S. SubbaRao. Oxford \& IBH Publishing Co.

\section{How to cite this article:}

Suman Samui, Sukanta Pal and Biplab Show. 2020. Effect of Biodegradable Municipal Compost and Chemical Fertilizer on Yield, Nutrient Content and Uptake of Kharif Rice in New Alluvial Zone of West Bengal. Int.J.Curr.Microbiol.App.Sci. 9(11): 922-928. doi: https://doi.org/10.20546/ijcmas.2020.911.110 